\title{
Metastasis of Renal Cell Carcinoma into the Thyroid Gland
}

\author{
Murat Dinçer ${ }^{1}$, Selvi Dinçer ${ }^{3}$, Aliseydi Bozkurt² ${ }^{2}$ Engin Kandıralı1', Atilla Semerciöz ${ }^{1}$ \\ ${ }^{1}$ Clinic of Urology, Bağcılar Trainig and Research Hospital, İstanbul, Turkey \\ 2Department of Urology, Erzincan University Faculty of Medicine, Erzincan, Turkey \\ ${ }^{3}$ Clinic of Radiation Oncology, Okmeydanı Training and Research Hospital, İstanbul, Turkey
}

\begin{abstract}
Renal cell cancer (RCC) is the most common cancer of the kidney. Thyroid gland rarest side of RCC metastasis which usually occur after 10 years. We present a very rare case of metastatic RCC in the thryoid gland in a patient who was referred to our clinic because of a neck mass 17 monts after radical nephrectomy. (JAREM 2015; 5: 78-9)
\end{abstract}

Keywords: Thyroid, renal cell cancer, metastasis

\section{INTRODUCTION}

Renal cell cancer (RCC) is the most common cancer of the kidney, and it constitutes $80 \%-85 \%$ of tumors in the kidney (1). The bones, liver, and lungs are the most common regions of metastasis for RCC. Metastasis is rarely seen in the thyroid gland and head-neck region. Thyroid metastases generally occur after 10 years (2). In our case report, a patient with RCC that spread to the thyroid gland, who was admitted 17 months after radical nephrectomy (RN), was examined.

\section{CASE PRESENTATION}

A 65-year-old female patient was admitted to our hospital with the complaint of a mass in the neck. The anamnesis of the patient revealed that she underwent left RN (clear cell carcinoma) for RCC 17 months ago. As a result of general surgery consultation, the mass was diagnosed as multinodular goiter. Based on hormonal evaluation, it was detected that she had hypothyroidism. Moreover, hypoactive nodules were found in the thyroid scintigraphy. The result of fine needle aspiration biopsy (FNAB) was benign. Bilateral total thyroidectomy was performed for suspected hypoactive nodules. In the pathological evaluation, the tumor cells displayed an alveolar sequence with a fine vascular network between them. Although immunoreactivity with RCC, CD19, and vimentin was immunohistochemically observed in malignant cells, no positivity was found with TTF-1. The case was diagnosed with RCC based on histopathological and immunohistochemical findings. No additional therapy was needed, and the follow-up protocol was initiated for the patient.

\section{DISCUSSION}

Metastatic tumors constitute $2 \%-3 \%$ of thyroid malignancies (3). Although thyroid nodules are encountered frequently, metastatic thyroid nodules are rare (4). The most common cancer types that show metastases to the thyroid gland are breast, lung, and kidney cancers. Metastatic thyroid lesions often do not present with any signs. RCC that spreads to the thyroid gland constitutes $12 \%-34 \%$ of all secondary thyroid tumors (5). In total, $85 \%$ of general distant organ metastases in RCC are seen within 3 years following primary resection. However, some cases with metastases that occurred a few decades later have also been reported $(6,7)$. Thyroid metastases generally occur after 10 years (2). However, in our case, thyroid metastasis appeared 17 months after RN. It should be kept in mind that an early metastatic lesion can be seen in a patient with a mass in the neck and a history of RCC diagnosis.

The guidelines recommend the procedure of FNAB for patients having a thyroid nodule and a history of RCC (1). However, cytological findings can be similar for primary and secondary tumors, and a metastatic tumor can be diagnosed as a primary thyroid tumor. Moreover, differentiated thyroid cancers, lung and salivary gland secondary tumors, and paragangliomas that have a clear cell histopathology should also be considered (8). In the differential diagnosis of a metastatic clear cell tumor, CD10 (Figure 1) and vimentin (Figure 2) are positive but thyroglobulin, calcitonin, and TTF-1 are negative immunohistochemically (9). Thyroid metastatic tumors can be found as a single nodule or as multiple nodules, and most of them are found as euthyroid. Symptoms occur depending on the compression caused by the growing thyroid gland. Although no feature was found in the FNAB in our case, hypoactive nodules were detected in the thyroid scintigraphy; therefore, total thyroidectomy was performed. Thyroidectomy must be applied for the treatment of RCC that shows isolated thyroid metastasis $(9,10)$.

In the pathological examination of the thyroid gland in our case, she was evaluated to have RCC metastasis, and thyroid- 


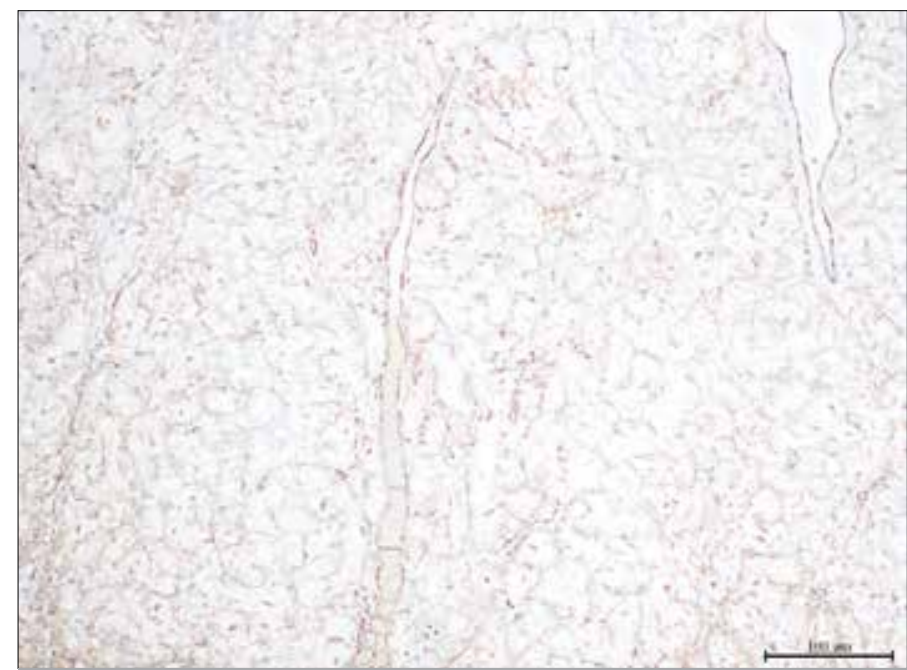

Figure 1. Malignant tumor infiltration in the thyroid tissue: CD10 $\times 10$

ectomy was performed as the appropriate treatment method for the case.

\section{CONCLUSION}

Thyroid metastases should be kept in mind for patients who had a thyroid nodule and a history of RCC. The differentiation of primary and secondary tumors is possible only by the pathological examination of suspected thyroid nodules. The treatment for RCC with isolated thyroid metastasis is thyroidectomy.

Informed Consent: Informed consent document was written and signed by the patient.

Peer-review: Externally peer-reviewed.

Author contributions: Concept - M.D., E.K.; Design - S.D., M.D.; Supervision - E.K., A.S.; Resource - A.S., A.B.; Materials - S.D., M.D.; Data Collection and/or Processing - E.K., M.D.; Analysis and/or Interpretation - A.B., S.D.; Literature Search - S.D., E.K.; Writing - M.D., E.K.; Critical Reviews - M.D.

Conflict of Interest: No conflict of interest was declared by the authors.

Financial Disclosure: The authors declared that this study has received no financial support.

\section{REFERENCES}

1. Chin CJ, Franklin JH, Moussa M, Chin JL. Metastasis from renal cell carcinoma to the thyroid 12 years after nephrectomy. CMAJ 2011; 183: 1398-9.[CrossRef]

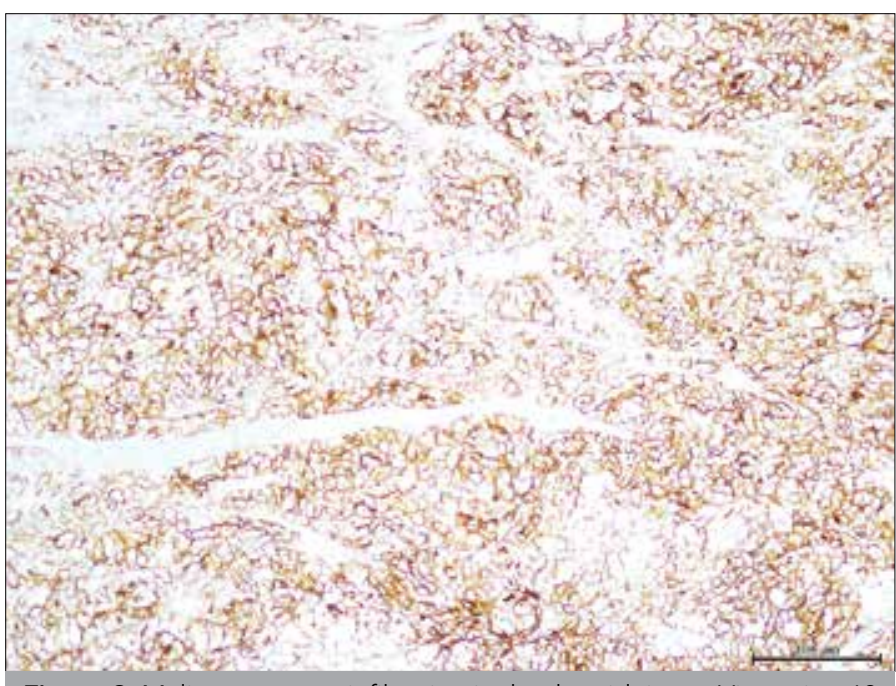

Figure 2. Malignant tumor infiltration in the thyroid tissue: Vimentin $\times 10$

2. lesalnieks I, Trupka A, Raab M, Glockzin G, Woenckhaus M, Schlitt HJ, Agha A. Renal cell carcinoma metastases to the thyroid gland-8 cases reported. Thyroid 2007; 17: 49-52. [CrossRef]

3. Bohn OL, De las Casas LE, Leon ME. Tumor-to-tumor metastasis: Renal cell carcinoma metastatic to papillary carcinoma of thyroid. Report of a case and review of the literature. Head Neck Pathol 2009; 3: 327-30. [CrossRef]

4. Romero Arenas MA, Ryu H, Lee S, Morris LF, Grubbs EG, Lee JE, et al. The role of thyroidectomy in metastatic disease to the thyroid gland. Ann Surg Oncol 2014; 21: 434-9. [CrossRef]

5. Medas F, Calò PG, Lai ML, Tuveri M, Pisano G, Nicolosi A. Renal cell carcinoma metastasis to thyroid tumor: a case report and review of the literature. J Med Case Rep 2013; 7: 265. [CrossRef]

6. Kihara M, Yokomise $H$, Yamauchi A. Metastasis of renal cell carcinoma to the thyroid gland 19 years after nephrectomy: a case report. Auris Nasus Larynx 2004; 31: 95-100. [CrossRef]

7. Wada N, Hirakawa S, Rino Y, Hasuo K, Kawachi K, Nakatani Y, et al. Solitary metachronous metastasis to the thyroid from renal clear cell carcinoma 19 years after nephrectomy: report of a case. Surg Today 2005; 35: 483-7.[CrossRef]

8. Stevens TM, Richards AT, Bewtra C, Sharma P. Tumors metastatic to thyroid neoplasms: a case report and review of the literature. Patholog Res Int 2011; 7: 238693. [CrossRef]

9. Koul H, Huh JS, Rove KO, Crompton L, Koul S, Meacham RB, et al. Molecular aspects of renal cell carcinoma: a review. Am J Cancer Res 2011; 1: 240-54.

10. Chung AY, Tran TB, Brumund KT, Weisman RA, Bouvet M. Metastases to the thyroid: a review of the literature from the last decade. Thyroid 2012; 22: 258-68. [CrossRef] 